\title{
The Variation of the Diastase Content in Lactating Mothers' Urine and Arakawa's Reaction of Mothers' Milk on Administration of Vitamin $B^{*}$ and Yakriton.
}

r31st Report of the Peroxidase Reaction.

By

\section{Shiu Sato.}

(佐藤 秀)

(From the Department of Pediatrics, Faculty of Medicine, Tohoku Imperial University, Sendai.

Director: Prof. A. Sato.)

\section{Introduction.}

In a preceding paper, ${ }^{1}$ I experienced that the diastase content in lactating mothers' urine is small in Arakawa-negative cases and large in Arakawa-positive cases. So it may be easily considered that if vitamin $B$ is administered for Arakawa-negative mothers, the urine diastase content of these cases will begin to increase. I used yakriton too in combination with vitamin $B$, because yakrition will mobilizet vitamin $B$ in the body, though I experimented on the sole use of the hormone without the use of vitamin $B$ in one case.

\section{Method and Matericls.}

Method:-Fis cher's ${ }^{2)}$ colorimetric method.

Materials:-I used the urine of mothers who visited our Outpatient Department on account of their sick infants. Of course it was

* $B_{1}$ is meant throughout the article.

$\dagger$ Cf. M. Ciba and J. A be, Jika Zassi, 1931, 1431.

A. Takamats u, Tohoku J. Exp. Med., 1934, 23, 327.

J. K i mu ra, Tohoku J. Exp., Med., 1936, 28, 55.

1) Sh. S at o, Tohokí J. Exp. Med., 1939, 37, 392.

2) O. Fischer, Klin. Wochenschr, 1936, 791. 
impossible to collect one whole day's urine. But urine was obtained in the morning between $9 \mathrm{a} . \mathrm{m}$. and $11 \mathrm{a} . \mathrm{m}$. A certain comparison of the diastase content may be made.

Vitamin B:-I used Injectio oryzain (Sankyo) and Injectio metabolin (Takeda).

\section{Results.}

In case 1 in Table 1 , the very large content of the diastase decreased on an administration of vitamin B (Cf. Case 1 in Table 1).

In Case 1 in Table 3, the diastase content in mothers' urine showed no remarkable variation even by combined use of vitamin $B$ and yakriton (Cf. Case 1 in Table 3).

\section{Table 1.}

The variation of the diastase content in urine of mothers with Arakawa-negative milk, on an administration of vitamin $B$.

\begin{tabular}{|c|c|c|c|c|c|}
\hline $\begin{array}{c}\text { No. of } \\
\text { exp. }\end{array}$ & $\begin{array}{l}\text { Diagnosis and } \\
\text { age of infant }\end{array}$ & Date & $\begin{array}{c}\text { Araka wa's } \\
\text { reaction }\end{array}$ & $\begin{array}{l}\text { Vitamin } B_{2} \\
(\text { mgrms. })\end{array}$ & $\begin{array}{l}\text { Diastase } \\
\text { content (Units } \\
\text { per minute and } \\
\text { per } 100 \text { c.c.) }\end{array}$ \\
\hline \multirow{5}{*}{1} & \multirow{5}{*}{$\begin{array}{c}\text { Eutrophy and } \\
\text { pharyngitis } \\
\text { (4 monthis) }\end{array}$} & 23. XII & 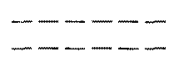 & $\rightarrow$ & 3000 \\
\hline & & $7 . I$ & $\begin{array}{l}- \pm+++1 \\
- \pm+++1\end{array}$ & $\begin{array}{c}\text { After } \\
2 \text { injections } \\
\text { of } 0.5\end{array}$ & 1600 \\
\hline & & 16. I & $\begin{array}{l}--\cdots-ー \pm \\
-\cdots---\end{array}$ & $\begin{array}{c}\text { After } \\
2 \text { injections } \\
\text { of } 0.5\end{array}$ & 2650 \\
\hline & & 23. I & $-\cdots-\cdots$ & $\begin{array}{c}\text { After } \\
5 \text { injections } \\
\text { of } 0.5\end{array}$ & 1950 \\
\hline & & 5. II & $--\rightarrow--\frac{1}{-}$ & $\begin{array}{c}\text { After } \\
3 \text { injections } \\
\text { of } 0.5\end{array}$ & 2150 \\
\hline \multirow{5}{*}{2} & \multirow{5}{*}{$\begin{array}{l}\text { Delicats } \\
\text { infant } \\
(17 \text { days })\end{array}$} & 28. XII & - & - & 900 \\
\hline & & 31. XII & $\begin{array}{l}-\cdots-\cdots \\
---\cdots\end{array}$ & $\begin{array}{c}\text { After } \\
2 \text { injections } \\
\text { of } 0.5\end{array}$ & 650 \\
\hline & & 4. I & $\begin{array}{l}---\cdots \\
----\cdots\end{array}$ & $\begin{array}{c}\text { After } \\
2 \text { injections } \\
\text { of } 0.5\end{array}$ & 1000 \\
\hline & & 6.1 & $\begin{array}{r}--- \pm \pm \\
--- \pm \pm\end{array}$ & $\begin{array}{c}\text { After } \\
\text { an injection } \\
\text { of } 0.5\end{array}$ & 1150 \\
\hline & & 7. I & $\begin{array}{l}---\cdots \\
---\cdots\end{array}$ & Ditto & 1150 \\
\hline
\end{tabular}




\begin{tabular}{|c|c|c|c|c|c|}
\hline $\begin{array}{l}\text { No. of } \\
\text { exp. }\end{array}$ & $\begin{array}{l}\text { Diagnosis and } \\
\text { age of infant }\end{array}$ & Date & $\begin{array}{l}\text { Arakawa's } \\
\text { reaction. }\end{array}$ & $\begin{array}{l}\text { Vitamin } \mathbf{B}_{\mathbf{l}} \\
\text { (mgrms.) }\end{array}$ & $\begin{array}{c}\text { Diastase } \\
\text { content (Units } \\
\text { per minute and } \\
\text { per } 100 \text { c.c.) }\end{array}$ \\
\hline \multirow{4}{*}{3} & \multirow{4}{*}{$\begin{array}{l}\text { Infantile pre- } \\
\text { beriberi and } \\
\text { bypotrophy } \\
\text { ( } 2 \text { months) }\end{array}$} & 2. II & 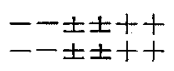 & - & 600 \\
\hline & & 7. II & $\begin{array}{l}-++H+H+\# \\
- \pm \pm+++\end{array}$ & $\begin{array}{l}\text { Pulv, oryzanin } \\
5 \text { grms. per } \\
\text { os daily }\end{array}$ & 850 \\
\hline & & 14. II & $\begin{array}{l}-t+H+++ \\
- \pm \pm+++\end{array}$ & Ditto & 1250 \\
\hline & & 19. II & $\begin{array}{l}-+H+H \#+H \\
- \pm \pm++H\end{array}$ & Ditto & 1300 \\
\hline \multirow{4}{*}{4} & \multirow{4}{*}{$\begin{array}{l}\text { Acute dys- } \\
\text { pepsia and } \\
\text { eczema } \\
\text { (5 months) }\end{array}$} & 28. II & $\begin{array}{l}------ \\
------\end{array}$ & - & 750 \\
\hline & & 2. III & $\begin{array}{l}------ \\
------\end{array}$ & $\begin{array}{c}\text { Since } 28 . \mathrm{II}_{\text {, }} \\
\text { an injection } \\
\text { of } 0.5 \text { daily }\end{array}$ & 1000 \\
\hline & & 4. III & $\begin{array}{l}--\cdots-\cdots \\
------\end{array}$ & Ditto & 1600 \\
\hline & & 8. III & $\begin{array}{l}-++++t \\
---1\end{array}$ & Ditto & 1450 \\
\hline \multirow{2}{*}{5} & \multirow{2}{*}{$\begin{array}{l}\text { B-avita- } \\
\text { minotic } \\
\text { dyspepsia } \\
\text { (a month) }\end{array}$} & 4. II & $\begin{array}{l}---\cdots \\
---\cdots\end{array}$ & $\rightarrow$ & 1600 \\
\hline & & 8. II & $\begin{array}{l}----- \\
-----\end{array}$ & $\begin{array}{c}\text { After } \\
2 \text { injections } \\
\text { of } 0.1\end{array}$ & 1950 \\
\hline
\end{tabular}

TABLE 2.

The variation of the diastase content in urine of mothers with Arakawa negative milk, on an administration of yakriton.

\begin{tabular}{|c|c|c|c|c|}
\hline $\begin{array}{c}\text { Diagnosis and age } \\
\text { of infant }\end{array}$ & Date & $\begin{array}{l}\text { Arakawa's } \\
\text { reaction }\end{array}$ & $\begin{array}{l}\text { Yakriton } \\
\text { (R.A.T. })\end{array}$ & $\begin{array}{c}\text { Diastase } \\
\text { content (Units } \\
\text { per rninute and } \\
\text { per } 100 \text { c.c.) }\end{array}$ \\
\hline \multirow{5}{*}{$\begin{array}{c}\text { Empyema and } \\
\text { hereditary syphilis } \\
\text { ( } 7 \text { months) }\end{array}$} & 2. III & $\begin{array}{l}- \pm \pm++ \\
-- \pm \pm++\end{array}$ & - & 1250 \\
\hline & 4. III & $\begin{array}{l} \pm++1++ \\
-+1+1+\end{array}$ & - & 900 \\
\hline & 6. III & $\begin{array}{l}- \pm+++H \\
---- \pm+\end{array}$ & $\begin{array}{c}\text { Aftor } \\
2 \text { injections } \\
\text { of } 1 / 2\end{array}$ & 1250 \\
\hline & 28. III & $\begin{array}{l}+H+H H+ \\
\pm+H H H H\end{array}$ & $\begin{array}{c}\text { After } \\
7 \text { injections } \\
\text { of } 1 / 2\end{array}$ & 1600 \\
\hline & 26. IJI & 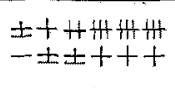 & $\begin{array}{c}\text { After } \\
2 \text { injections } \\
\text { of } 1 / 2\end{array}$ & 2150 \\
\hline
\end{tabular}

* R.A.U. = Rabbit Ammonia Units. 
TABle 3.

The variation of the diastase content in urine of mothers with Arakawanegative milh, on an administration of vitamin $B_{1}$ and yakriton.

\begin{tabular}{|c|c|c|c|c|c|c|}
\hline $\begin{array}{c}\text { No. of } \\
\text { exp. }\end{array}$ & $\begin{array}{c}\text { Diagnosis } \\
\text { and age of } \\
\text { infant }\end{array}$ & Date & $\begin{array}{c}\text { Arakawa's } \\
\text { reaction }\end{array}$ & $\begin{array}{l}\text { Vitamin } B_{1} \\
\text { (mgrms.) }\end{array}$ & $\begin{array}{l}\text { Yakriton } \\
\text { (R.A.U.) }\end{array}$ & $\begin{array}{l}\text { Diastase con- } \\
\text { tent (Units } \\
\text { per minute } \\
\text { per } 100 \text { c.c.) }\end{array}$ \\
\hline \multirow{4}{*}{1} & \multirow{4}{*}{$\begin{array}{c}\text { Infantile } \\
\text { per- } \\
\text { beriberi } \\
(2 \text { months })\end{array}$} & $\cdot 18 . \mathrm{XII}$ & $---\cdots--$ & 一 & - & 1000 \\
\hline & & 21. XII & --- \pm \pm \pm & $\begin{array}{c}\text { After } \\
2 \text { injections } \\
\text { of } 0.1\end{array}$ & - & 400 \\
\hline & & 31. XII & $\begin{array}{l}- \pm \pm+1 \\
- \pm \pm+1\end{array}$ & $\begin{array}{c}\text { After } \\
4 \text { injections } \\
\text { of } 0.1\end{array}$ & $\begin{array}{c}\text { After } \\
3 \text { injections } \\
\text { of } 1 / 2\end{array}$ & 900 \\
\hline & & 8. I & {$\left[\begin{array}{l}- \pm \pm++1 \\
- \pm \pm+1\end{array}\right.$} & $\begin{array}{c}\text { After } \\
6 \text { injections } \\
\text { of }-0.1 \\
\end{array}$ & $\begin{array}{c}\text { After } \\
2 \text { injections } \\
\text { of } 1 / 2\end{array}$ & 900 \\
\hline \multirow{5}{*}{2} & \multirow{5}{*}{$\begin{array}{c}\text { Atrophy } \\
(7 \text { months })\end{array}$} & 13. I & $\begin{array}{l}-- \pm \pm \pm \\
--- \pm \pm \pm\end{array}$ & - & - & 550 \\
\hline & & 18. I & ----1 & $\begin{array}{c}\text { After } \\
4 \text { injections } \\
\text { of } 0.1\end{array}$ & - & 900 \\
\hline & & 23.1 & $\begin{array}{l}-- \pm \pm \pm \\
- \pm \pm++1\end{array}$ & $\begin{array}{c}\text { After } \\
2 \text { injections } \\
\text { of } 0.1 \\
\end{array}$ & $\begin{array}{c}\text { After } \\
2 \text { injections } \\
\text { of } 1 / 2\end{array}$ & 1450 \\
\hline & & 27. I & $\left|\begin{array}{l}- \pm \pm++4 \\
- \pm \pm+++1\end{array}\right|$ & Ditto & Ditto & 1250 \\
\hline & & 4. II & $\begin{array}{l}- \pm \pm+1 \\
\pm++4+4\end{array}$ & $\begin{array}{c}\text { After } \\
3 \text { injections } \\
\text { of } 0.1 \\
\end{array}$ & $\begin{array}{c}\text { After } \\
3 \text { injections } \\
\text { of } 1 / 2\end{array}$ & 1950 \\
\hline \multirow{5}{*}{. . } & \multirow{5}{*}{$\begin{array}{c}\text { B-avita- } \\
\text { minotic } \\
\text { dyspepsia } \\
\text { (2 months) }\end{array}$} & 29.1 & 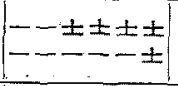 & - & - & 750 \\
\hline & & 3. II & $-\cdots \pm \pm \pm$ & $\begin{array}{c}\text { After } \\
2 \text { injections } \\
\text { of } 0.05\end{array}$ & - & 550 \\
\hline & & 8. II & {$\left[\begin{array}{c}--\cdots \\
-\end{array}\right.$} & & $\begin{array}{c}\text { After } \\
2 \text { injections } \\
\text { of } 1 / 2\end{array}$ & 550 \\
\hline & & 13. II & -- \pm++1 & & Ditto & 900 \\
\hline & & 18. II & $-\cdots-\cdots$ & & Ditto & 1150 \\
\hline \multirow{3}{*}{4} & \multirow{3}{*}{$\begin{array}{l}\text { Pharygitis } \\
(7 \text {-months })\end{array}$} & 4. III & $\mid+++4+4+1+4$ & - & - & 1250 \\
\hline & & 11. III & $----\div$ & \multirow{2}{*}{$\begin{array}{l}\text { Since } 10 . \\
\text { III, liq. } \\
\text { oryzanin } \\
20 \text { c.c. per } \\
\text { os daily }\end{array}$} & 一 & 1250 \\
\hline & & 16. III & $---\cdots$ & & $\begin{array}{c}\text { After } \\
\text { an injeetion } \\
\text { of } 1 / 2\end{array}$ & 2150 \\
\hline
\end{tabular}




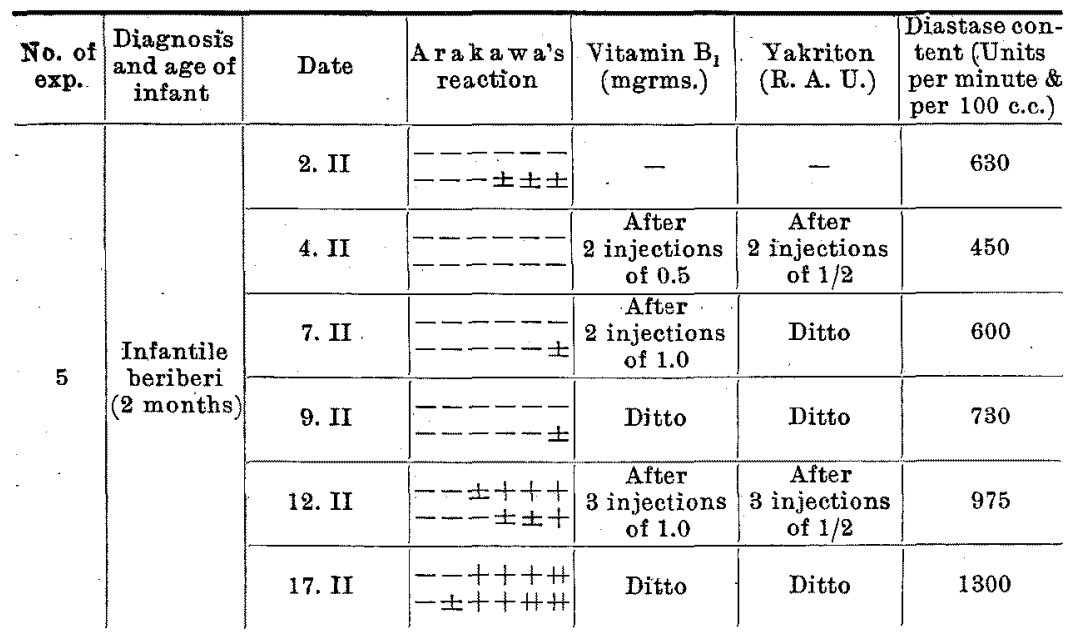

And in all the other cases, the diastase content increased gradually but did not amount to far over 2000 units. Some of them showed an initial temporary decrease (Cf. Case 2 in Table 1, Table 2 and Cases 3 and 5 in Table 3).

\section{Comment.}

The small value of the diastase content in urine of mothers who secreted Arakawa-negative milk increased in most cases on an administration of vitamin B, yakriton, or vitamin $B$ and yakriton, though an initial temporary decrease of the content was seen. But in the present examination, I could not find a remarkable difference of effect in each three above-mentioned methods of administration as in the case of the methyl glyoxal-like substance in mothers' milk in my preceding work. ${ }^{3)}$ Arakawa's reaction did not always improve, though it was not difficult to presume a gradual decrease of the methyl glyoxallike substance. It is very interesting that, in Case 1 in Table 1 , the enormous value of diastase content decreased instead of increasing on an administration of vitamin $\mathrm{B}$, and came to a normal value (Cf. Table 1 in a preceding paper ${ }^{1)}$ of mine). I assumed in that paper, that an enormous value of the diastase content in urine may also be pathological, just as a small value of it is pathological. In this respect, the experiment of Groebbels ${ }^{4)}$ is noteworthy, who states that in B-

3) Sh. Sat o, Tohoku J. Exp. Med., 1939, 37, 230.

4) F. Groebbels, Hoppe-Seylers Zeitschr., 1922, 122, 104. 
avitaminotic rat, carbohydrate metabolism rises temporarily in the initial period, then in order to fall gradually.

Hereupon I tried the following hypothesis as the relation between Arakawa's reaction and vitamin $B$. In the beginning of avitaminosis B, Arakawa's reaction and some elements in the milk or urine may possibly show an apparent vitamin B-rich condition-for instance, an increase of the diastase content in urine. Then in the beginning of the administration of vitamin $\mathrm{B}$ (or yakriton, or vitamin $B$ and yakriton) to Arakawa-negative case, A rakawa's reaction and some elements in the milk may possibly show an apparent state inclined to B-avitaminosis, instead of improvement,-for instance, the initial temporary decrease of the diastase content in urine and the weakening of Arakawa's reaction due to an initial ${ }^{3)}$ temporary increase of the methyl glyoxal-like substance in milk.

\section{Conclusions.}

In a preceding paper the diastase content of the urine of mothers with human milk negative to Araka wa's reaction is generally small, while in Arakawa-positive mothers it is generally large.

The poor value of the diastase content in urine of mothers with Arakawa-negative milk will become larger to a value seen in Arakawapositive cases on an administration of vitamin $B$, yakriton, or vitamin $\mathrm{B}$ and yakriton.

It is thus probable that Arakawa-negative mothers are generally in a state of $\mathrm{B}$-avitaminosis. 